\title{
KOMUNIKASI TERAPEUTIK CLINICAL INSTRUCTOR DI RUMAH SAKIT JIWA PROVINSI JAWA BARAT
}

\author{
Ane Herfira, Lucy Pujasari Supratman \\ Prodi S1 Ilmu Komunikasi Fakultas Komunikasi dan Bisnis Universitas Telkom
}

\begin{abstract}
ABSTRAK
Clinical Instructor atau pembimbing klinik adalah seorang perawat professional yang terpilih yang ahli dalam praktek klinik keperawatan. Seorang Clinical Instructor memiliki jobdesk yang salah satunya adalah membimbing dan mengarahkan peserta didik. Peserta didik yang dimaksud dalam hal ini adalah mahasiswa yang sedang melakukan Praktek Kerja Lapangan (PKL) pada rumah sakit tersebut. Sesuai dengan jobdesk tersebut, seorang Clinical Instructor harus memiliki pengetahuan yang lebih dalam bidangnya, yaitu kesehatan khususnya keperawatan. Berdasarkan pra penelitian yang dilakukan peneliti, peneliti mensurvey secara langsung bahwa terdapat perbedaan antara pemahaman teori dengan praktik komunikasi terapeutik di Rumah Sakit Jiwa Provinsi Jawa Barat. Perbedaan teori dan praktek yang terjadi adalah tentang hubungan komunikasi terapeutik. Dengan adanya kesalahpahaman ini maka teori tentang komunikasi terapeutik dan hubungan terapeutik ini akan terus menerus salah pemahaman kedepannya. Jenis penelitian ini adalah penelitian kualitatif dengan studi kasus. Data dari penelitian ini diperolah dari hasil wawancara, observasi dan juga dokumentasi. Informan dalam penelitian ini diperoleh dengan cara snowball sampling. Peneliti bertemu dengan satu clinical instructor untuk dijadikan informan. Informan berikutnya didapatkan dari rekomendari yang diberikan oleh informan pertama. Berdasarkan hasil penelitian dapat disimpulkan bahwa pemahaman dan penerapan komunikasi terapeutik oleh clinical instructor di Rumah Sakit Jiwa Provinsi Jawa Barat ini dirasa masih kurang. Beberapa clinical instructor masih ada yang kurang memahami tentang teknik komunikasi non-terapeutik, komunikasi paraverbal dan juga tentang hubungan terapeutik. Selain itu untuk penerapan teknik komunikasi non-terapeutik dan komunikasi verbal dirasa masih kurang maksimal. Komunikasi non-terapeutik dikatakan seperti komunikasi seperti biasa atau untuk di rumah sakit tersebut sering disebut dengan istilah komunikasi sosial.

Kata kunci: Komunikasi, Terapeutik, Pembimbing Klinik, Rumah Sakit Jiwa, Provinsi Jawa Barat
\end{abstract}

\section{FACTORS THAT INFLUENCE THE PERCEPTION OF EDUCATION TOWARDS PERMENDIKNAS NUMBER 702009 ABOUT INCLUSIVE EDUCATION}

\begin{abstract}
Clinical Instructor is a professional nurse who selected experts in nursing clinical practice. A Clinical Instructor has a job that one of them is guiding and directing learners. Learners are referred to in this case are the college students who are doing the Job Training at the hospital. In accordance with the job description, a Clinical Instructor must have a deeper knowledge of the field, which is health, especially in the field of nursing. Based on the prestudy conducted by researchers, researchers surveyed firsthand that there is a difference between understanding theory to practice therapeutic communication at the Mental Hospital of West Java Province. Given these misconceptions, the theory of therapeutic communication
\end{abstract}


and therapeutic relationship will continually misunderstanding in the future. The research is a qualitative research with case study approach. The data obtained in this study are from interviews, observation and documentation. Informants in this study was obtained by snowball sampling. Researchers met with a clinical instructor to serve as informants. The next informant obtained from the recommendation given by the first informant. Based on the results of this study concluded that the understanding and application of therapeutic communication by a clinical instructor at the Mental Hospital of West Java province it is still lacking. Some of clinical instructor, still lacking in understanding about non-therapeutic communication techniques, communication paraverbal and also about the therapeutic relationship. In addition to the application of non-therapeutic communication techniques and verbal communication is still not optimal. Communication is described as non-therapeutic communication as usual or for the hospital's often referred to as social communication.

Keywords : Communication, Therapeutic, Clinical Instructor, Physciatric Hospital, West Java Province

Korespondensi: Ane Herfira. Universitas Telkom. Jl. Telekomunikasi, Jl. Terusan Buah Batu No.01, Dayeuhkolot, Bandung, Jawa Barat 40257.Email: ane.herfira@ gmail.com

\section{PENDAHULUAN}

Clinical Instructor atau pembimbing klinik adalah seorang perawat professional yang terpilih yang ahli dalam praktek klinik keperawatan. Seorang Clinical Instructor memiliki jobdesk yang salah satunya adalah membimbing dan mengarahkan peserta didik. Peserta didik yang dimaksud dalam hal ini adalah mahasiswa yang sedang melakukan Praktek Kerja Lapangan (PKL) pada rumah sakit tersebut. Sesuai dengan jobdesk tersebut, seorang Clinical Instructor harus memiliki pengetahuan yang lebih dalam bidangnya, yaitu kesehatan khususnya keperawatan. Ratna Indraswati (2003) dalam artikelnya mengemukakan tentang peran pembimbung klinik, bahwa keberadaan pembimbing klinik sebagai bagian dari tim program pendidikan keperawatan di lingkungan praktik klinik sangat diperlukan dalam mencapai kompetensi dan meningkatkan rasa percaya diri mahasiswa keperawatan.

Rumah Sakit Jiwa Provinsi Jawa Barat adalah satu-satunya rumah sakit yang secara administratif berada di bawah pengelolaan Pemerintah Provinsi Jawa Barat. Pada rumah sakit ini, memiliki Clinical Instructor yang bertugas untuk membimbing para mahasiswa keperawatan yang sedang melakukan Praktek Kerja Lapangan (PKL) di rumah sakit tersebut. Selain itu, seorang clinical instructor juga masih berhubungan langsung kepada pasien untuk melakukan suatu terapi atau pengobatan dengan tujuan untuk membuat pasien sembuh. Clinical instructor harus mampu menguasai praktik dan juga teori tentang keperawatan dengan baik. Karena, seorang clinical instructor melakukan bimbingan kepada para mahasiswa keperawatan. 
Berdasarkan prapenelitian yang dilakukan peneliti, peneliti mensurvey secara langsung bahwa terdapat perbedaan antara pemahaman teori dengan praktik komunikasi terapeutik di Rumah Sakit Jiwa Provinsi Jawa Barat. Perbedaan teori dan praktek yang terjadi adalah tentang hubungan komunikasi terapeutik. Dengan adanya kesalahpahaman ini maka teori tentang komunikasi terapeutik dan hubungan terapeutik ini akan terus menerus salah pemahaman kedepannya. Hal ini yang mendasari peneliti untuk meneliti tentang pemahaman komunikasi terapeutik oleh clinical intructor atau pembimbing klinik di Rumah Sakit Jiwa Provinsi Jawa Barat. Dengan ini, peneliti hendak mengangkat penelitian yang berjudul Komunikasi Terapeutik Clinical Instructor (CI) di Rumah Sakit Jiwa Provinsi Jawa Barat. Adapun pertanyaan dalam penelitian ini sebagai berikut: Bagaimana penerapan komunikasi terapeutik clinical instructor di Rumah Sakit Jiwa Provinsi Jawa Barat?

Menurut Kamus Besar Bahasa Indonesia (2016) arti dari kata terapeutik adalah berkaitan dengan sebuah terapi atau pengobatan. Komunikasi terapeutik merupakan aspek penting yang harus dimiliki oleh perawat dalam melaksanakan asuhan keperawatan pada klien. Komunikasi yang diterapkan oleh perawat kepada klien merupakan komunikasi terapeutik yang mempunyai tujuan untuk mencapai kesembuhan klien. Selain itu, komunikasi terapeutik merupakan komunikasi yang direncanakan secara sadar, tujuan dan kegiatannya difokuskan untuk menyembuhkan klien.

Menurut (Depkes RI, 1997) yang tercantum pada buku Komunikasi Terapeutik dalam Keperawatan Jiwa karangan Ridhyalla Afnuhazi, komunikasi terapeutik adalah komunikas yang mendorong proses penyembuhan klien. Komunikasi terapeutik termasuk komunikasi interpersonal dengan titik tolak memberikan pengertian antara perawat dengan klien. (Afnuhazi, 2015: 32)

$$
\text { Hays dan Larson dalam }
$$

Townsend,2011 mengidentifikasi sejumlah teknik-teknik untuk membantu para perawat dalam berinteraksi lebih terapeutik dengan klien. Ini adalah "prosedur teknis" yang dilakukan oleh perawat yang bekerja di psikiatri, dan mereka harus melayani pasien untuk meningkatkan pengembangan hubungan antara perawat dengan pasien. Dalam buku Suryani (2015: 57) dalam menanggapi pesan yang disampaikan klien, perawat dapat menggunakan berbagai teknik komunikasi terapeutik, yakni sebagai berikut:

1. Bertanya

Bertanya merupakan teknik yang dapat mendorong klien untuk mengungkapkan perasaan dan pikirannya. Teknik berikut ini sering digunakan pada tahap orientasi. 
a. Pertanyaan Fasilitatif dan Nonfasilitatif

membutuhkan jawaban yang singkat.

Pertanyaan fasilitatif diajukan

2. Mendengarkan

apabila pada saat bertanya, perawat

bersikap sensitive terhadap pikiran dan perasaan klien. Karena pertanyaannya tersebut berhubungan dengan masalah yang dihadapi klien. Sebaliknya, pertanyaan nonfasilitatif adalah pertanyaan yang tidak efektif, karena pertanyaan yang diberikan bersifat tifak focus pada masalah atau pembicaraan, terkesan mengancam serta tampak kurang pengertian terhadap klien.

b. Pertanyaan Terbuka dan Pertanyaan Tertutup

Pertanyaan terbuka digunakan apabila perawat membutuhkan banyak jawaban dari klein. Menurut Antai-Otong (2008) dalam (Suryani, 2015: 58), pertanyaan terbuka memungkinkan perawat mendapatkan informasi atau tanggapan yang lebih banyak dan mendalam tentang perilaku klien, hal tersebut dilakukan dengan menggunakan kata tanya yang menuntut jawaban yang panjang. Pertanyaan terbuka dapat diawali dengan kata "apa" dan "bagaimana", sedangkan pertanyaan tertutup digunakan ketika perawat Mendengarkan merupakan dasar utama dalam komunikasi terapeutik. Mendengarkan adalah sutau proses yang aktif dan dinamis, karena perawat menggunakan seluruh perhatian serta pikirannya dalam mendengarkan dan mengobservasi ungkapan verbal dan nonverbal klien (Antai-Otong dalam Suryani, 2015: 60)

3. Mengulang

Mengulang memiliki pengertian mengulang kembali pikiran utama yang telah diekspresikan oleh klien. Hal ini menunjukkan bahwa perawat mendengarkan memvalidasi, menguatkan, serta mengembalikan perhatian klien pada sesuatu yang telah diucapkan klien

4. Klarifikasi

Klarifikasi merupakan strategi menanggapi respon klien dengan mengecek kebenaran informasi yang disampaikan oleh klien. (Frisch dan Frisch, 2011 dalam Suryani, 2015: 61). Klarifikasi dapat dilakukan dengan meminta klien mengulang apa yang disampaikannya dengan mengatakan,"Maaf saya masih kurang jelas tentang apa yang ibu atau bapak katakan tadi. Bisa lebih diperjelas?"

5. Refleksi 
Refleksi adalah mengarahkan kembali ide, perasaan, pertanyaan dan isi pembicaraan klien. Hal ini digunakan untuk memvalidasi pengertian perawat terhadap ungkapan klien, serta menekankan empati, minat, dan penghargaan terhadap klien (Frisch dan Frisch, 2011 dalam Suryani, 2015: 62). Teknik refleksi terdiri dari refleksi isi dan refleksi perasaan.

6. Memfokuskan

Penggunaan teknik memfokuskan ditujukan untuk memberi kesempatan kepada klien untuk membahas masalah inti dan mengarahkan komunikasi klien pada pencapaian tujuan. (Frisch dan Frisch, 2011 dalam Suryani, 2015: 63). Dengan demikian, focusing akan menghindari pembicaraan tanpa arah dan penggantian topik pembicaraan. Teknik focusing juga sangat bermanfaat pada fase kerja. Teknik ini efektif untuk mengatasi pembicaraan yang berbelitbelit.

7. Diam

Teknik diam digunakan untuk memberikan kesempatan pada klien sebelum menjawab pertanyaan perawat. Diam akan memberikan kesempatan kepada perawat dan klien untuk mengorganisasikan pikiran masingmasing. Teknik ini tidak sama dengan teknik mendengarkan. Pada teknik ini, perawat memberikan waktu pada klien untuk memikirkan dan menyusun informasi yang ingin disampaikan kepada perawat.

8. Memberi informasi

Memberi informasi merupakan tindakan penyuluhan kesehatan untuk klien. Teknik ini sangat membantu dalam mengajarkan klien tentang kesehatan, aspek-aspek yang relevan dengan perawatan yang dijalani, serta proses penyembuhan klien. Teknik ini tidak sama dengan teknik advice. Pada teknik ini perawat hanya memberikan informasi, sedangkan keputusan tetap ada pada klien.

9. Mengubah cara pandang

Teknik mengubah cara pandang digunakan untuk memberikan cara pandang lain sehingga klien tidak melihat sesuatu masalah dari aspek negatifnya saja (Gerald, 1998 dalam Suryani, 2015: 66). Teknik ini sangat bermanfaat, terutama ketika klien berpikiran negatif terhadap sesuatu.

10. Menyimpulkan

Menyimpulkan adalah teknik komunikasi yang membantu klien mengeksplorasi poin penting dari interaksi perawat-klien. Teknik ini membantu perawat dan klien untuk memiliki pemikiran dan ide yang sama saat mengakhiri pertemuan. 
11. Eksplorasi

Teknik ini bertujuan untuk mencari atau menggali lebih jauh masalah yang dialami klien (Frisch dan Frisch, 2011 dalam Suryani, 2015: 67)). Teknik ini sangat bermanfaat pada tahap kerja untuk mendapatkan gambaran yang detail tentang masalah yang dialami klien.

12. Membagi persepsi

Menurut Stuart dan Laraia (2001) dalam (Suryani, 2015: 68), membagi persepsi adalah meminta pendapat klien tentang hal yang perawat rasakan atau pikirkan. Teknik ini digunakan ketika perawat merasakan atau melihat adanya perbedaan antara respon verbal dan respon nonverbal klien.

13. Mengidentifikasi tema

Perawat harus tanggap terhadap cerita yang disampaikan klien, serta harus mampu menangkap tema dari pembicaraan tersebut. Tujuannya adalah meningkatkan pengertian dan menggali masalah penting Stuart dan Laraia (dalam Suryani, 2015: 69)

14. Humor

Humor memiliki beberapa fungsi dalam hubungan terapeutik perawat-klien. Suatu pengalaman pahit sangat baik ditangani dengan humor, karena humor dapat menyediakan tempat bagi emosi untuk distraksi dari perasaan stres dan depresi.

\section{Memberi pujian}

Memberikan pujian merupakan keuntungan psikologis yang didapatkan klien ketika berinteraksi dengan perawat. Memberi pujian dapat diungkapkan dengan kata-kata ataupun melalui isyarat nonverbal. Dengan katakata misalnya, "saya merasa bangga sekali hari ini, karena anda telah mampu merapikan tempat tidur dan mandi sendiri”.

\section{Teknik Komunikasi Non-Terapeutik}

Beberapa pendekatan dianggap hambatan untuk membuka komunikasi antara perawat dengan klien. Hays dan Larson (dalam Townsend: 2011) mengidentifikasi sejumlah teknik ini. Perawat harus mengenali dan menghilangkan penggunaan teknik tersebut dalam hubungan antara perawat dengan klien. Menghindari teknik ini akan memaksimalkan efektivitas komunikasi dan meningkatkan hubungan perawat dengan klien.

1. 1. Memberi jaminan

Memberi jaminan artinya menyatakan sesuatu kepada klien yang belum pasti hasilnya dengan maksud menenangkan klien. Teknik ini kurang tepat, karena apabila hal tersebut tidak terjadi sesuai dengan harapan, klien menjadi tidak percaya lagi atau bahkan menjadi marah pada perawat. 
2. Memberi penilaian

Teknik ini erat kaitannya dengan kemampuan perawat dalam memahami dan mengklarifikasi nilai-nilai yang dianutnya. Teknik ini dianggap kurang tepat, karena dapat mengakibatkan klien merasa perawat mengabaikan perasaan atau merendahkan dirinya (Kozier dan Erb, dalam Suryani, 2015: 72).

3. Memberi komentar klise

Memberi komentar klise artinya memberikan komentar yang itu-itu saja atau komentar yang terlalu umum. Sebagai contoh, setiap klien melakukan atau menjawab sesuatu dengan tepat, perawat mengatakan "bagus". Komentar seperti itu dapat membuat klien bosan.

4. Memberi saran

Memberi saran kepada klien adalah tindakan yang tidak terapeutik, karena apabila saran tersebut tidak mampu mengatasi masalah, klien akan menyalahkan atau memulangkannya pada perawat (Gerald, dalam Suryani, 2015: 73). Biasanya tindakan ini dilakukan oleh perawat dengan terburuburu, tanpa menggali lebih dalam masalah lebih dalam masalah klien yang sesungguhnya.

5. Defensive

Defensive merupakan respons bertahan dengan pendapatnya dan tidak mau berubah. Respons perawat yang defensive dapat menghambat klien dalam mengungkapkan perasaanya. Dengan bersikap defensif, perawat seakan menutupi kekurangan dan kelemahannya. Respon defensif juga menunjukkan bahwa perawat kurang peduli dengan kebutuhan klien.

\section{Hubungan Terapeutik}

Komunikasi terapeutik mempunyai tujuan dan berfungsi sebagai terapi bagi klien, karena itu pelaksanaan komunikasi terapeutik harus direncanakan dan terstruktur dengan baik. Hubungan terapeutik terdiri dari empat tahapan, yaitu:

1. Fase Pra Interaksi

Tahap ini adalah masa persiapan sebelum memulai hubungan dengan klien.

2. Fase Orientasi

Fase ini dimulai pada saat bertemu pertama dengan klien. Saat pertama kali bertemu dengan klien fase ini digunakan perawat untuk berkenalan dengan klien dan merupakan langkah awal dalam membina hubungan saling percaya.

\section{Fase Kerja}

Tahap ini merupakan inti dari keseluruhan proses komunikasi terapeutik. Tahap ini perawat bersama klien mengatasi masalah yang dihadapi oleh klien. Tahap ini berkaitan dengan pelaksaan rencana asuhan yang telah ditetapkan. Teknik komunikasi terapeutik yang sering digunakan perawat antara lain mengeksplorasi, mendengarkan dengan 
aktif, refleksi, berbagai persepsi, menyadari pesan verbal dan non verbal yang memfokuskan dan menyimpulkan.

\section{Fase Terminasi}

Fase ini merupakan fase yang sulit dan penting, karena hubungan saling percaya sudah terlena dan berada pada tingkat optimal. Bisa terjadi terminasi pada saat perawat mengakhiri tugas pada unit tertentu atau saat klien akan pulang.

\section{Jenis Komunikasi Terapeutik}

Jenis komunikasi yang paling lazim digunakan dalam pelayanan keperawatan di rumah sakit adalah pertukaran informasi secara verbal terutama pembicaraan dengan tatap muka. Komunikasi verbal biasanya lebih akurat dan tepat waktu. Kata-kata adalah alat atau simbol yang dipakai untuk mengekspresikan ide atau perasaan, membangkitkan respon emosional, atau menguraikan obyek, observasi dan ingatan. Sering juga untuk menyampaikan arti yang tersembunyi, dan menguji minat seseorang. Keuntungan komunikasi verbal dalam tatap muka yaitu memungkinkan tiap individu untuk merespon secara langsung.

Selain komunikasi verbal, tentu komunikasi nonverbal. Komunikasi nonverbal adalah pesan yang disampaikan tidak secara verbal ataupun tulisan (Frisch dan Fricsh, dalam Suryani, 2015: 41). Komunikasi nonverbal merupakan cara yang paling meyakinkan untuk menyampaikan pesan kepada orang lain. Perawat perlu disampaikan klien mulai dari saat pengkajian hingga evaluasi, karena isyarat nonverbal menambah makna terhadap pesan verbal.

Bukan hanya komunikasi verbal dan nonverbal, ada pula komunikasi paraverbal. Komunikasi paraverbal adalah komunikasi yang disampaikan melalui nada, intonasi dan suara bukan apa perkataan yang disebutkan. Maksud yang disampaikan dapat diterima dengan makna yang berbeda-beda jika disampaikan dalam nada dan intonasi yang berbeda-beda juga.

\section{METODE PENELITIAN}

Paradigma yang digunakan peneliti dalam penelitian ini adalah parardigma konstruktivis. Paradigma ini hampir merupakan antithesis terhadap paham yang menempatkan pentingnya pengamatan dan objektivitas dalam menemukan suatu realitas atas ilmu pengetahuan. (Salim, 2006: 71). Sedangkan untuk pendekatannya peneliti menggunakan metode penelitian kualitatif.

Jenis penelitian yang digunakan adalah studi deskriptif. Dalam penelitian ini, informan yang digunakan adalah clinical instructor yang bekerja di Rumah Sakit Jiwa Provinsi Jawa Barat. Dalam pemilihan informan, peneliti menggunakan teknik sampling snowball. Sesuai namanya, teknik ini bagaikan bola salju yang turun mengelinding dari puncak gunung ke lembah, semakin lama semakin membesar 
ukurannya. Jadi, teknik ini merupakan teknik penentuan sampel yang awalnya berjumlah kecil, kemudian berkembang semakin banyak. Orang yang dijadikan sampel pertama diminta memilih atau menunjuk orang lain untuk dijadikan sampel lagi, begitu seterusnya sampai jumlahnya lebih baik (Burhan Bungin, 2008: 160)

\section{HASIL DAN PEMBAHASAN}

\section{Penerapan Komunikasi Terapeutik}

\section{Clinical Instructor}

Hubungan terapeutik adalah Salah satu tugas utama dari seorang clinical instructor adalah menjadi pembimbing mahasiswa yang sedang melakukan praktek kerja lapangan (PKL) di rumah sakit tersebut. Selain membimbing mahasiswa, seorang clinical instructor juga masih menangani seorang pasien. Untuk berhadapan dengan pasien, komunikasi yang digunakan adalah komunikasi terapeutik. Dalam komunikasi terapeutik, hubungan komunikasi terapeutik yang dilakukan perawat kepada pasien harus diperhatikan pada setiap fasenya. Fase pada hubungan terapeutik adalah sebagai berikut:

\section{a. Fase Pra-Interaksi}

Dalam melakukan hubungan terapeutik, fase yang pertama dilakukan oleh seorang clinical instructor adalah fase pra-interaksi. Fase pra-interaksi sangat penting dilakukan sebelum berinteraksi dengan pasien. Pada tahap ini, clinical instructor menggali perasaan dan mengidentifikasi kelebihan dan kekurangan pada dalam dirinya. Clinical instructor juga mencari informasi tentang pasien, kemudian perawat merancang strategi untuk pertemuan pertama kepada pasien. Dalam fase pra-interaksi, seorang clinical instructor harus memperhatikan beberapa hal yaitu kelebihan dan kekurangannya, menggunakan teori yang sesuai dan antisipasi terhadap apa yang akan terjadi nanti. Clinical instructor di rumah sakit ini sudah mampu melakukan beberapa hal yang harus diperhatikan dalam fase prainteraksi dalam hubungan terapeutik kepada pasien.

\section{b. Fase Orientasi}

Fase selanjutnya dalam hubungan terapeutik adalah fase orientasi. Perkenalan merupakan kegiatan yang dilakukan seorang clinical instructor saat pertama kali bertemu dengan pasien. Pada saat berkenalan, perawat harus memperkenalkan dirinya terlebih dahulu kepada pasien. Dengan memperkenalkan dirinya terlebih dahulu, berarti perawat telah bersikap terbuka pada pasien. Hal ini diharapkan akan mendorong pasien untuk membuka dirinya. Tahap perkenalan dilaksanakan pada setia awal pertemuan, baik pada pertemuan pertama, kedua, dan selanjuntnya. Tujuan dari tahap ini adalah memvalidasi keakuratan data dan rencana yang telah dibuat dengan keadaan pasien saat ini, serta mengevaluasi hasil 
tindakan yang lalu. Clinical instructor di Rumah Sakit Jiwa Provinsi Jawa Barat melakukan validasi dan juga pengkajian dalam fase orientasi. Selain itu para clinical instructor juga menanyakan tentang kegiatan apa yang sudah dilakukan sebelumnya kepada pasien. Memulai perbincangan tentang topic umum juga salah satu yang dilakukan oleh para clinical instrucror pda fase orientasi ini.

\section{c. Fase Kerja}

Fase kerja ini merupakan inti dari keseluruhan proses komunikasi terapeutik. Pada tahap ini, clinical instructor dan pasien bekerja sama untuk mengatasi masalah yang dihadapai klien. Tahap ini berkaitan dengan pelaksanaan rencana asuhan yang telah ditetapkan. Tahap kerja adalah rangkaian yang dilakukan perawat sesuai dengan rencana tindakan. Dalam fase kerja ini terdapat teknik komunikasi terapeutik dan teknik komunikasi non terapeutik. Teknik komunikasi terapeutik adalah teknik yang digunakan dalam menghadapi pasien saat melakukan komunikasi terapeutik. Pada rumah sakit ini, teknik komunikasi terapeutik yang sering digunakana adalah teknik focusing dan juga teknik klarifikasi. Di dalam fase kerja, juga terdapat beberapa yang harus diperhatikan saat melakukan komunikasi terapeutik kepada pasien yaitu komunikasi verbal, komunikasi non verbal dan komunikasi paraverbal.

\section{Komunikasi Verbal}

Dalam melakukan komunikasi terapeutik, komunikasi verbal yang digunakan harus diperhatikan. Komunikasi verbal adalah komunikasi yang paling lazim dilakukan. Komunikasi verbal yang dilakukan kepada pasien bertujuan untuk melihat bagaimana respon pasien tersebut saat diajak berkomunikasi. Salah satu hal yang harus diperhatikan pada komunikasi verbal adalah memperhatikan kalimat.

\section{Komunikasi Non Verbal}

Komunikasi non-verbal adalah pesan yang disampaikan tidak secara verbal atau tulisan. Dalam komunikasi terapeutik, komunikasi nonverbal pun harus diperhatikan saat melakukan komunikasi terapeutik kepada pasien. Dalam komunikasi non-verbal diperhatikan untuk menambah pesan yang disampaikan oleh pasien. Beberapa hal yang harus diperhatikan dalam komunikasi non verbal adalah ekspresi wajah, body language, dan sentuhan kepada pasien.

\section{Komunikasi Paraverbal}

Selain komunikasi verbal dan non-verbal, komunikasi paraverbal juga sangat penting untuk diperhatikan dalam melakukan 
komunikasi terapeutik kepada pasien. harus diperhatikan dalam fase pra-interaksi Komunikasi paraverbal adalah intonasi dalam hubungan terapeutik kepada pasien. suara. Komunikasi paraverbal yang clinical instructor di Rumah Sakit Jiwa dilakukan oleh clinical instructor adalah Provinsi Jawa Barat melakukan validasi dan sesuai dengan keadaan dari pasien yang juga pengkajian dalam fase orientasi. dalam mereka hadapi. Jika pasien tersebut adalah pasien amuk, makanya intonasi yang fase kerja disinilah seorang clinical instructor menggunakan teknik komunikasi terapeutik digunakan merendah dan jika menghadapi pasien yang diem, maka menggunakan intonasi menurun.

\section{d. Fase Terminasi}

Selain memahami dengan baik tentang komunikasi terapeutik, seorang clinical instructor juga dituntut untuk mampu menerapkan komunikasi terapeutik dengan baik kepada pasien. Penerapan komunikasi terapeutik yang baik kepada pasien mampu membantu pasien untuk mencapai titik kesembuhannya. Dalam melakukan fase terminasi di rumah sakit tersebut, para clinical instructor melakukan evaluasi objektif dan juga subjektif saat bertemu dengan pasien.

\section{SIMPULAN}

Dalam fase pra-interaksi seorang clinical instructor harus memperhatikan beberapa hal yaitu kelebihan dan kekurangannya, menggunakan teori yang sesuai dan antisipasi terhadap apa yang akan terjadi nanti. Clinical instructor di rumah sakit ini sudah mampu melakukan beberapa hal yang yang ada dan digunakan sesuai dengan kebutuhannya. Dalam fase ini teknik yang paling banyak digunakan adalah teknik focusing dan klarifikasi. Untuk teknik komunikasi non-terapeutik beberapa informan menganggap teknik komunikasi non-terapeutik adalah komunikasi sosial yaitu komunikasi yang dapat dilakukan kapan saja, namun salah satu informan mengatakan bahwa teknik komunikasi nonterapeutik adalah teknik yang sebaiknya dihindari saat melakukan komunikasi terapeutik dan teknik tersebut dibagi menjadi dua yaitu verbal dan non verbal. selain memperhatikan teknik komunikasi terapeutik yang digunakan, clinical instructor juga memperhatikan komunikasi verbal, nonverbal dan juga paraverbal. Untuk komunikasi verbal, clinical instructor memperhatikan kalimat yang digunakan saat berhadapan langsung dengan pasien. Untuk komunikasi non-verbal clinical instructor memperhatikan muka dan juga body language yang diberikan oleh pasien. Dan untuk komunikasi paraverbal, clinical instructor menggunakannya sesuai dengan kondisi pasien. Jika pasien dengan riwayat 
penyakit amuk maka menggunakan nada tinggi dan jika pasien diam maka menggunakan nada menurun. Pada fase terminasi clinical instructor melakukan evaluasi objektif dan evaluasi subjektif. Evaluasi objektif adalah evaluasi materi. Jadi sudah sejauh mana pasien memahami pembicaraan yang sudah dilakukan sebelumnya. Dan evaluasi subjektif adalah evaluasi perasaan. Evaluasi yang bertujuan untuk mengetahui bagaimana perasaan pasien setelah melakukan komunikasi terapeutik dengan perawat.

\section{DAFTAR PUSTAKA}

Afnuhazi, Ridhyalla. 2015. Komunikasi Terapeutik Dalam Keperawatan Jiwa, Yogyakarta: Gosyen Publishing

Bungin, Burhan. 2006. Sosiologi Komunikasi. Jakarta: Kencana Prenada Media Group.

Octavianti, Meria. 2016. Komunikasi Nonverbal Proksemik di Rumah Tidak Layak Huni. Jurnal Kajian Komunikasi Unpad: Bandung

Salim, Agus. 2006. Teori \& Paradigma Penelitian Sosal. Yoygakarta: Tiara Wacana.

Suryani, 2015. Komunikasi Terapeutik Teori \& Praktek, Jakarta: Penerbit Buku Kedokteran.

Tohirin. 2013. Metode Penelitian Kualitatif dalam Pendidikan Dana Bimbingan Konseling, Depok: RajaGrafindo Persada.

Townsend, Mary C. 2011. Essentials of Psychiatric Mental Health Nursing Concepts of care in Evidence-Based Practice. United States of America: DavisPlus

Zasbaruden. Diakses dari http: //www.slideshare.net/zasbaruden pada Senin 30 Januari 2017 pukul 01.43 WIB 